\title{
HUBUNGAN SISTEM BAGI HASIL DI LEMBAGA KEUANGAN SYARI'AH DENGAN KEINGINAN NASABAH UNTUK BERINVESTASI DI BPR SYARIAH BANGUN DRAJAT WARGA YOGYAKARTA
}

\author{
Ahmad Danu Syaputra ${ }^{1}$ \\ ${ }^{1}$ Sekolah Tinggi Ilmu Ekonomi (STIE) MURA Lubuklinggau
}

\begin{abstract}
ABSTRAK
Bagi hasil menurut terminologi asing (Inggris) dikenal dengan profit sharing. Profit sharing dalam kamus ekonomi diartikan pembagian laba. Secara definitif profit sharing diartikan distribusi beberapa bagian dari laba pada para pegawai dari suatu perusahaan. Bagi hasil dapat diartikan penentuan besarnya rasio atau nisbah berdasar atas keuntungan yang diperoleh secara nyata. Dengan demikian pelaksanaan bagi hasil hanya terjadi apabila adanya keuntungan dari usaha yang dijalankan, sehingga pada perbankan syariah tidak dikenal dengan keuntungan pasti akan tetapi bagi hasil ditentukan kepasitasnya setelah mendapat keuntungan.

Penelitian ini bertujuan untuk menganalisis adanya sistem bagi hasil yang digunakan di BPR Syariah Bangun Drajat Warga dengan sikap nasabah dalam berinvestasi dan untuk mengetahui ada tidaknya peluang perkembangan perbankan Islam sehubungan dengan sistem bagi hasil dan sikap nasabah dalam berinvestasi. Alat analisis statistik yang digunakan adalah korelasi Product Moment Pearson dengan mengolah data-data yang didapat melalui penyebaran angket kepada nasabah BPR Syariah Bangun Drajat Warga Yogyakarta.

Hasil penelitian menunjukkan terdapat hubungan antara sistem bagi hasil dengan keinginan berinvestasi. Hal ini ditunjukkan dari tingkat korelasi sebesar $\left(\mathrm{r}_{\text {hitung }}\right) 0,770>0,361\left(\mathrm{r}_{\text {tabel }}\right.$ pada taraf signifikan 5\%) dan nilai $p$-value $0,000<$ 0,05 , maka $\mathrm{H}_{0}$ ditolak dan $\mathrm{H}_{1}$ diterima yang berarti bahwa terdapat hubungan antara sistem bagi hasil dengan keinginan berinvestasi nasabah.
\end{abstract}

Kata kunci: Sistem Bagi Hasil, Keinginan Berinvestasi, Bank Syariah. 


\title{
Islãmadîna \\ JURNAL PEMIKIRAN ISLAM
}

Volume XVIII, No. 2, Juni 2017 : 21-40

\begin{abstract}
SYSTEM RELATIONSHIP FOR RESULT IN SYARI'AH FINANCIAL INSTITUTIONS WITH THE CUSTOMER'S DESIRE TO INVEST IN BPR SYARIAH BANGUN DRAJAT YOGYAKARTA
\end{abstract}

Profit sharing by foreign terminology (English) is known as profit sharing. Definitively profit sharing means the distribution of some portion of the profits to employees of a company. Revenue sharing can be interpreted. Thus the schedule for the results that happen to have advantages of the business run, so the Islamic banking does not know with certainty will definitely result entangled results kepasitasnya after a profit.

This study aims to analyze the existence of profit sharing system used in BPR Syariah Bangun Drajat Warga with the attitude of customers in investing and to determine whether there is an opportunity for development of Islamic banking in relation with profit sharing system and customer attitude in investing. Statistical analysis tool used is Product Moment Pearson correlation by processing the data obtained through questionnaires to customers of BPR Syariah Bangun Drajat Warga Yogyakarta.

The results showed there is a relationship between profit sharing system with the desire to invest. This is indicated from the correlation level of (rhitung) $0.770>0.361$ (rtabel at 5\% significant level) and p-value 0,000<0,05, then $\mathrm{H} 0$ is rejected and $\mathrm{H} 1$ is accepted which means that there is a relationship between profit sharing system with the desire to invest Customers.

Keywords: Profit Sharing System, Investment Desire, Sharia Bank. 


\section{PENDAHULUAN}

perkembangan perbankan mempunyai peranan yang sangat penting dalam proses pembangunan ekonomi secara nasional. Peranan yang sangat penting tersebut disebabkan oleh fungsi bank sebagai lembaga keuangan yang menjadi perantara bagi orang yang memiliki kelebihan dana dan orang yang kekurangan dana. Karena itulah perbankan mempunyai peranan yang sangat penting dalam pembangunan ekonomi, terutama dalam membiayai aktivitas yang berhubungan dengan uang.

Pada awal bulan oktober 2008, krisis keuangan terutama dunia perbankan yang hebat terjadi di Amerika Serikat dan negara Indonesia juga terkena dampaknya. Pada tanggal 8 Oktober 2008, IHSG tertekan tajam turun 10,38 \%, yang membuat pemerintah panik dan terpaksa menghentikan (suspen) kegiatan pasar modal beberapa hari. Krisis ekonomi global yang terjadi saat ini disebabkan oleh sistem keuangan konvensional. Hal itu akibat bermainnya spekulasi. (Republika edisi senin 13 Otober 2008)

Akan tetapi, konflik kepentingan semacam itu tidak kita jumpai pada lembaga keuangan syariah. Kepentingan penyandang dana, pemilik bank dan pemakai dana dapat diharmonisasikan. Kepentingan ketiga pihak tersebut paralel, yakni memperoleh imbalan bagi hasil sesuai dengan keadaan yang sesungguhnya (Muhammad, 2005). Karena itu, pemerintah mendorong penerapan sistem keuangan syariah yang diyakini bisa membawa situasi perekonomian dunia menjadi lebih stabil. Para pakar ekonomi meyakini sistem keuangan syariah bisa menjadi alternatif dalam menghadapi krisis keuangan ini.

Berawal dari kondisi itulah orang mulai melirik konsep ekonomi islam yang selama ini dianggap teori kuno dan usang. Perbankan Syariah yang berlandasakan pada sistem bagi hasil saat ini ternyata disambut antusias dan diminati oleh masyarakat dengan berbondong-bondong datang dan menginvestasikan dananya di perbankan syariah, dan sejumlah bank mulai memberikan pelatihan dalam bidang perbankan syariah bagi para stafnya. Sebagian bank tersebut ingin menjajaki untuk membuka divisi atau cabang syariah dalam institusinya.

Sebagian lainnya bahkan berencana mengkonversi diri sepenuhnya menjadi bank syariah. Angin segar itu sungguh terasa bagi perbankan syariah untuk lebih leluasa dalam mengembangkan sayapnya. Hingga akhirnya dalam perkembangannya diikuti oleh semaraknya lahir lembaga keuangan syariah berupa asuransi syariah, koperasi syariah dan bisnis syariah lainnya.

Banyaknya masyarakat yang datang untuk menginvestasikan dananya di 


\section{Islãmadîna \\ JURNAL PEMIKIRAN ISLAM}

perbankan syariah ini diduga kuat karena sistem yang digunakan pada perbankan syariah, yaitu menggunakan sistem bagi hasil. Hal ini dibuktikan dengan total dana pihak ketiga (DPK) perbankan syariah nasional pada akhir tahun 2010 mencapai Rp. 76 triliun, tumbuh 45,31\% dibandingkan akhir tahun 2009 dengan nilai Rp. 53,3 triliun. Jumlah nasabah diperkirakan sekitar 6 juta nasabah. (http://bataviase.co.id/node/567657 diakses pada tanggal 16 maret 2011)

Pada sisi yang lain pangsa pasar bank syariah meningkat tajam dan semakin membesar terhadap bank konvensional, pada tahun 2010 perbankan syariah mencatatkan aseet sebesar Rp. 100,26 triliun yang terdiri dari bank umum syariah dan unit usaha syariah sebesar Rp. 97,52 triliun. Bank pembiayaan syariah (BPRS) sebesar 2,74 triliun atau mencapai pangsa pasar sebesar 3.1\% dari total industri perbankan di tanah air. (http://zonaekis.com, diakses tanggal 09 Maret 2011)

Sedangkan di Yogyakarta sendiri pada tahun 2010 mengalami perkembangan yang sangat mengagumkan dengan tingkat pertumbuhan melebihi perkembangan perbankan konvensional dengan total aset sebesar Rp. 1.532 triliun meningkat sebesar $19,04 \%$ dari tahun 2009. Perkembangan perbankan syariah di Yogyakarta merupakan yang tertinggi di Indonesia dengan pangsa pasar mencapai 5,78\% di tahun 2010 dari total aset perbankan. Share tersebut ternyata melebihi share perbankan syariah nasional. (http://zonaekis.com/pertumbuhan-perbankan-syariah-di-yogya-lampaui-perban kan-konvensional diakses pada tanggal 09 maret 2011)

Perkembangan perbankan syariah di Indonesia sedemikian mengesankan sehingga mendapat predikat "the biggest and the fastest growing Islamic banking market in the world". Namun demikian perkembangan perbankan syariah tersebut merupakan tantangan dan sekaligus amanah bagi seluruh stakeholder perbankan syariah untuk terus mengembangkan dan merumuskan berbagai sistem ekonomi dan perbankan yang sesuai dengan prinsip syari'ah. Upaya untuk mengembangkan sistem ekonomi dan perbankan syariah tersebut perlu dilakukan secara terintegrasi baik pada tingkatan pembuat kebijakan, praktisi, akademisi, alim ulama dan masyarakat.

Maka selaku akademisi dalam rangka mendukung pengembangan ekonomi yang berbasis syari'ah, maka menarik untuk dilakukan penyelidikan empiris mengenai hubungan sistem bagi hasil di lembaga keuangan syari'ah dengan keinginan nasabah untuk berinvestasi di perbankan syari'ah di BPR Syariah Bangun Drajat Warga Yogyakarta. 
Berdasarkan uraian tersebut dirumuskan suatu permasalahan yaitu: Apakah terdapat hubungan antara sistem bagi hasil dengan keinginan nasabah berinvestasi di bank syari'ah?

\section{LANDASAN TEORI}

\section{Bagi Hasil}

Bagi hasil menurut terminologi asing (Inggris) dikenal dengan istilah Profit Sharing, yang dalam kamus ekonomi diartikan sebagai pembagian laba. Secara definisi, profit sharing diartikan sebagai distribusi beberapa bagian dari laba pada para pegawai dari suatu perusahaan. Lebih lanjut, bagi hasil itu dapat berbentuk suatu bonus uang tunai tahunan yang didasarkan pada laba yang diperoleh tahun-tahun sebelumnya atau dapat berbentuk pembayaran mengguan atau bulanan (muhammad, $2005: 105$ )

Istilah bagi hasil merupakan kesepakatan antara pemberi dana dalam hal ini ialah bank syariah dengan penerima dana atau disebut juga dengan nasabah untuk saling memberi keuntungan yang diperoleh atas penggunaan dana tersebut sesuai dengan kesepakatan yang telah disepakati bersama.

Menurut Sutan Remy Sjahdeini (1999;60), pengertian Bagi Hasil adalah Bagi Hasil adalah pembagian keuntungan yang diperoleh atas usaha antara pihak bank dan nasabah atas kesepakatan bersama dalam melakukan suatu kerjasama.

Pada mekanisme bank syari'ah, pendapatan bagi hasil ini berlaku untuk produk-produk penyertaan, baik penyertaan menyeluruh maupun sebagian-sebagian, atau bentuk korporasi (kerjasama). Inti mekanisme investasi bagi hasil pada dasarnya adalah terletak pada kerjasama yang baik antara Shahibul Maal yang bertindak sebagai penyedia dana dan Mudharib sebagai pengelola dana.

Jadi yang dimaksud dengan bagi hasil dapat diartikan penentuan besarnya rasio atau nisbah berdasar atas keuntungan yang diperoleh secara nyata. Dengan demikian pelaksanaan bagi hasil hanya terjadi apabila adanya keuntungan dari usaha yang dijalankan, sehingga pada perbankan syariah tidak dikenal dengan keuntungan pasti akan tetapi bagi hasil ditentukan kepasitasnya setelah mendapat keuntungan.

\section{Faktor - Faktor yang Mempengaruhi Bagi hasil}

Tujuan utama dari kontrak pembiayaan yang berprinsipka syirkah atau bagi hasil adalah memperoleh hasil investasi. Besar kecilnya hasil investasi dipengaruhi oleh banyak faktor. Faktor pengaruh tersebut ada yang berdampak 
langsung dan ada yang tidak langsung.

1. Faktor langsung

Diantara faktor - faktor langsung ( direct factors ) yang mempengaruhi perhitungan bagi hasil adalah investment rate, jumlah dana yang tersedia, dan nisbah bagi hasil ( profit sharing ratio )

a. Investment rate merupakan presentase aktual dana yang diinvestasikan dari total dana. Jika bank menetukan investment rate sebesar 80 persen, hal ini berarti 20 persen dari total dana dialokasikan untuk memenuhi likuiditas.

b. Jumlah dana yang tersedia untuk diinvestasikan merupakan jumlah dana dari berbagai sumber dana yang tersedia untuk diinvestasikan. Dana tersebut dapat dihitung dengan menggunakan salah satu metode :

1) Rata - rata saldo minimum bulanan.

2) Rata - rata saldo minimum harian.

c. Nisbah (profit sharing ratio)

1) salah satu ciri dari pembiayaan syirkah adalah nisbah yang harus ditentukan dan disetujui pada awal perjanjian.

2) Nisbah antara satu bank dengan bank lainnya dapat berbeda.

3) Nisbah juga dapat berbeda dari waktu ke waktu dalam satu bank.

4) Nisbah juga dapat berbeda antara satu account dengan account lainnya sesuai dengan besarnya dana dan jatuh temponya.

2. Faktor Tidak langsung

Faktor tidak langsung yang mempengaruhi bagi hasil, adalah :

a. Penentuan butir - butir pendapatan dan biaya.

1) Bank dan nasabah melakukan Share dalam pendapatan dan biaya. Pendapatan yang "dibagi - hasilkan" merupakan pendapatan yang diterima dikurangi biaya - biaya.

2) Jika semua biaya ditanggung pihak bank, maka hal ini disebut dengan revenue sharing

b. Kebijakan akunting (prinsip dan metode akuntansi)

Bagi hasil secara tidak langsung dipengaruhi oleh berjalannya aktivitas yang diterapkan terutama sehubungan dengan pengakuan pendapatan dan biaya. 


\section{Perbedaan Sistem Bunga dan Sistem Bagi Hasil}

Hal mendasar yang membedakan antara lembaga keuangan konvesional dan lembaga keuangan syari'ah adalah terletak pada pengembalian dan pembagian keuntungan yang diberikan nasabah kepada lembaga keuangan dan/atau yang diberikan lembaga keuangan kepada nasabah.

Perbedaan sistem bunga dan sistem bagi hasil pada lembaga keuangan konvensonal dan lembaga keuangan syari'ah terdapat pada tabel dibawah ini.

Perbedaan Sistem Bunga dan Sistem Bagi

\begin{tabular}{|c|c|c|}
\hline Karakteristik & Sistem Bunga & Sistem Bagi hasil \\
\hline $\begin{array}{l}\text { Penentuan besarnya } \\
\text { hasil }\end{array}$ & Sebelumnya & $\begin{array}{lr}\text { Sesudah } & \text { berusaha, } \\
\text { sesudah } & \text { ada } \\
\text { untungnya } & \end{array}$ \\
\hline $\begin{array}{l}\text { Yang ditentukan } \\
\text { sebelumnya }\end{array}$ & $\begin{array}{l}\text { Bunga, besarnya } \\
\text { nilai rupiah }\end{array}$ & $\begin{array}{l}\text { Menyepakati } \\
\text { proporsi pembagian } \\
\text { untung untuk } \\
\text { masing-masing } \\
\text { pihak. }\end{array}$ \\
\hline Jika terjadi kerugian & $\begin{array}{l}\text { Ditanggung nasabah } \\
\text { saja }\end{array}$ & $\begin{array}{l}\text { Ditanggung kedua } \\
\text { belah pihak, nasabah } \\
\text { dan lembaga }\end{array}$ \\
\hline Dihitung dari mana? & $\begin{array}{l}\text { Dari dana yang } \\
\text { dipinjamkan, fixed, } \\
\text { tetap }\end{array}$ & $\begin{array}{l}\text { Dari untung yang } \\
\text { bakal diperoleh, } \\
\text { belum tentu besarnya }\end{array}$ \\
\hline $\begin{array}{l}\text { Titik perhatian } \\
\text { proyek/usaha }\end{array}$ & $\begin{array}{l}\text { Besarnya bunga yang } \\
\text { harus dibayar } \\
\text { nasabah/pasti } \\
\text { diterima bank }\end{array}$ & $\begin{array}{l}\text { Keberhasilan proyek } \\
\text { / usaha jadi perhatian } \\
\text { bersama : nasabah } \\
\text { dan lembaga }\end{array}$ \\
\hline Berapa besarnya? & $\begin{array}{l}\text { Pasti. (\%) kali jumlah } \\
\text { pinjaman yang telah } \\
\text { pasti diketahui }\end{array}$ & $\begin{array}{l}\text { Proporsi }(\%) \text { kali } \\
\text { jumlah untung yang } \\
\text { belum diketahui = } \\
\text { belum diketahui }\end{array}$ \\
\hline Status hukum & $\begin{array}{l}\text { Berlawanan dengan } \\
\text { QS. Luqman : } 34\end{array}$ & $\begin{array}{l}\text { Melaksanakan } \\
\text { Luqman : } 34\end{array}$ \\
\hline
\end{tabular}

Sumber : M. Syafi'i Antonio, Bank Islam Teori dan Praktek, Jakarta : Tazkia Institute bekerja sama dengan Gema Insani Press, 2001

\section{Perhitungan Bagi Hasil}

Besarnya penentuan porsi bagi hasil antara kedua belah pihak ditentukan sesuai kesepakatan bersama, dan harus terjadi dengan adanya kerelaan (An-Tarodhin) 


\section{Islãmadîna \\ JURNAL PEMIKIRAN ISLAM}

Volume XVIII, No. 2, Juni 2017 : 21-40

di masing-masing pihak tanpa adanya unsur paksaan.

Mekanisme perhitungan bagi hasil yang diterapkan di dalam perbankan syari'ah terdiri dari dua sistem, yaitu: profit sharing, revenue sharing.

1. Pengertian Profit Sharing

Profit sharing menurut etimologi Indonesia adalah bagi keuntungan. Dalam kamus ekonomi diartikan pembagian laba (Muhammad, 2002: 101). Profit secara istilah adalah perbedaan yang timbul ketika total pendapatan (total revenue) suatu perusahaan lebih besar dari biaya total (total cost). (Cristopher dan Bryan Lowes, 1994: 534)

Di dalam istilah lain profit sharing adalah perhitungan bagi hasil didasarkan kepada hasil bersih dari total pendapatan setelah dikurangi dengan biaya-biaya yang dikeluarkan untuk memperoleh pendapatan tersebut (TPPS IBI, 2001: 264). Pada perbankan syariah istilah yang sering dipakai adalah profit and loss sharing, di mana hal ini dapat diartikan sebagai pembagian antara untung dan rugi dari pendapatan yang diterima atas hasil usaha yang telah dilakukan.

Sistem profit and loss sharing dalam pelaksanaannya merupakan bentuk dari perjanjian kerjasama antara pemodal (Investor) dan pengelola modal (enterpreneur) dalam menjalankan kegiatan usaha ekonomi, dimana di antara keduanya akan terikat kontrak bahwa di dalam usaha tersebut jika mendapat keuntungan akan dibagi kedua pihak sesuai nisbah kesepakatan di awal perjanjian, dan begitu pula bila usaha mengalami kerugian akan ditanggung bersama sesuai porsi masing-masing.

Kerugian bagi pemodal tidak mendapatkan kembali modal investasinya secara utuh ataupun keseluruhan, dan bagi pengelola modal tidak mendapatkan upah/hasil dari jerih payahnya atas kerja yang telah dilakukannya.

Keuntungan yang didapat dari hasil usaha tersebut akan dilakukan pembagian setelah dilakukan perhitungan terlebih dahulu atas biaya-biaya yang telah dikeluarkan selama proses usaha. Keuntungan usaha dalam dunia bisnis bisa negatif, artinya usaha merugi, positif berarti ada angka lebih sisa dari pendapatan dikurangi biaya-biaya, dan nol artinya antara pendapatan dan biaya menjadi balance. Keuntungan yang dibagikan adalah keuntungan bersih (net profit) yang merupakan lebihan dari selisih atas pengurangan total cost terhadap total revenue. 


\section{Pengertian Revenue Sharing}

Revenue Sharing berasal dari bahasa Inggris yang terdiri dari dua kata yaitu, revenue yang berarti; hasil, penghasilan, pendapatan. Sharing adalah bentuk kata kerja dari share yang berarti bagi atau bagian. Revenue sharing berarti pembagian hasil, penghasilan atau pendapatan. (Muhammad, 2002: 101)

Revenue (pendapatan) dalam kamus ekonomi adalah hasil uang yang diterima oleh suatu perusahaan dari penjualan barang-barang (goods) dan jasa-jasa (services) yang dihasilkannya dari pendapatan penjualan (sales revenue). (Cristopher dan Bryan Lowes, 1994: 583)

Dalam arti lain revenue merupakan besaran yang mengacu pada perkalian antara jumlah out put yang dihasilkan dari kagiatan produksi dikalikan dengan harga barang atau jasa dari suatu produksi tersebut. Di dalam revenue terdapat unsur-unsur yang terdiri dari total biaya (total cost) dan laba (profit). Laba bersih (net profit) merupakan laba kotor (gross profit) dikurangi biaya distribusi penjualan, administrasi dan keuangan (Cristopher dan Bryan Lowes, 1994: 473).

Berdasarkan devinisi di atas dapat di ambil kesimpulan bahwa arti revenue pada prinsip ekonomi dapat diartikan sebagai total penerimaan dari hasil usaha dalam kegiatan produksi, yang merupakan jumlah dari total pengeluaran atas barang ataupun jasa dikalikan dengan harga barang tersebut. Unsur yang terdapat di dalam revenue meliputi total harga pokok penjualan ditambah dengan total selisih dari hasil pendapatan penjualan tersebut. Tentunya di dalamnya meliputi modal (capital) ditambah dengan keuntungannya (profit).

Berbeda dengan revenue di dalam arti perbankan. Yang dimaksud dengan revenue bagi bank adalah jumlah dari penghasilan bunga bank yang diterima dari penyaluran dananya atau jasa atas pinjaman maupun titipan yang diberikan oleh bank.

Reveneu pada perbankan syari'ah adalah hasil yang diterima oleh bank dari penyaluran dana kedalam bentuk aktiva produktif, yaitu penempatan dana bank pada pihak lain. Hal ini merupakan selisih atau angka lebih dari aktiva produktif dengan hasil penerimaan bank (Muhammad, 2002:120). Akan tetapi perbankan syari'ah memperkenalkan kepada masyarakat dengan istilah reveneu sharing, yaitu sistem bagi hasil yang dihitung dari total pendapatan pengelola dana tanpa dikurangi dengan biaya pengelolaan dana. 


\section{Islãmadîna

Perbankan Syari'ah memperkenalkan sistem pada masyarakat dengan istilah Revenue Sharing, yaitu sistem bagi hasil yang dihitung dari total pendapatan pengelolaan dana tanpa dikurangi dengan biaya pengelolaan dana.

Lebih jelasnya Revenue sharing dalam arti perbankan adalah perhitungan bagi hasil didasarkan kepada total seluruh pendapatan yang diterima sebelum dikurangi dengan biaya-biaya yang telah dikeluarkan untuk memperoleh pendapatan tersebut. Sistem revenue sharing berlaku pada pendapatan bank yang akan dibagikan dihitung berdasarkan pendapatan kotor (gross sales), yang digunakan dalam menghitung bagi hasil untuk produk pendanaan bank.

\section{Contoh Perhitungan Bagi Hasil}

Muhammad (2005: 113), bapak A memiliki deposito Rp. 10 juta, jangka waktu satu bulan (1 Desember 1995 s/d 1 Januari 1996), dan nisbah bagi hasil antara nasabah dan bank 57\%: 43\%. Jika keuntungan bank yang di peroleh untuk deposito satu bulan per 31 Desember 1996 adalah Rp20 juta dan rata-rata deposisto jangka waktu 1 bulan adalah Rp950 juta, berapa keuntungan yang diperoleh Bapak A?

Jawab :

Keuntungan yang diperoleh Bapak A adalah :

(Rp10 juta / Rp950 juta) $\times$ Rp20 juta $\times 57 \%=$ Rp120.000

Pada tanggal1 Desember 1994, Bapak B membuka deposito sebesar Rp10 juta di Bank Non Syariah, jangka waktu satu bulan, dengan tingkat buga $9 \%$ p.a berapa bunga yang diperoleh pada saat jatuh tempo?

Jawab :

Bunga yang di perolh Bapak B adalah :

$($ Rp10 juta $x 31$ hari $x$ 9\%)/365 hari $=$ Rp76.438

Dari contoh di atas dapat di simpulkan bahwa pada dasarnya, bank bagi hasil memberi keuntungan kepada deposan dengan pendekatan Financing to Deposito Rate (FDR), sedangkan bank konvensional dengan pendekata biaya. Artinya, dalam menghitung pendapatan, bank bagi hasil menimbang rasio antara dana pihak ketiga dan pembiayaan yang di berikan, serta pendapatan yang dihasilkan dari perpaduan dua factor tersebut. Sedangkan bank konvensional langsung menganggap semua bunga yang diberikan adalah biaya, tanpa memperhitungkan berapa pendapatan yang dapat 
dihasilkan dari dana yang dihimpun tersebut. (Muhammad, 2005: 114)

\section{Investasi}

Menurut Jogiyanto (2000 : 2)investasi adalah penundaan konsumsi sekarang untuk komsumsi di masa yang akan datang. Investasi juga diartikan sebagai penundaan konsumsi sekarang untuk digunakan di dalam produksi yang efisien selama waktu tertentu.

Menurut Sunariyah (2003 : 4), investasi adalah penanaman modal untuk satu atau lebih aktiva yang dimiliki dan biasanya berjangka waktu lama dengan harapan mendapatkan keuntungan di masa-masa yang akan datang.

Pada perbankan syariah dapat berupa tabungan dengan menggunakan akad mudharabah dan wadi'ah (titipan). Khusus untuk akad mudharabah yang dipraktikan dalam perbankan syariah adalah bank syariah sebagai pihak kedua atau pihak pertama. Dengan demikian, bank menjalankan dua fungsi dalam satu institusi. Pada transaksi pertama bank bertindak sebagai mudharib yang menerima amanah dalam bentuk sumber dana investasi mudharabah dari investor atau nasabah, baik dalam bentuk tabungan maupun deposito. Sedangkan fungsi kedua bank dapat bertindak sebagai pemilik dana atau shahibul maal yaitu dengan cara melakukan pembiayaan mudharabah kepada mudharib atau pelaku usaha.

Investasi sendiri digolongkan menjadi dua jenis yaitu real assets dan financial assets. Real assets sendiri berupa barang seperti kendaraan, bangunan, tanah dan lainnya. Sedangkan financial assets berupa surat-surat berharga. Dalam prakteknya orang lebih cenderung memilihi financial assests karena lebih liquid ketimbang real assets. Tujuan dari menginvestasikan dana atau modal itu sendiri tidak lain adalah untuk mendatangkan keuntungan dimasa yang akan datang.

Investasi bank syariah tidak seperti bank konvensional, bank syariah menjamin pembayaran kembali nilai nominal dari investasi mudharabah. Bank syariah juga tidak menjamin keuntungan atas investasi mudharabah. Berbeda dengan bank konvensional yang menjamin keuntungan atas deposito berdasarkan tingkat bunga tertentu dengan perbaikan performance-nya (Muhammad, 2005: 268).

\section{Perbedaan Menabung dan Membungakan Uang}

Ada dua perbedaan mendasar antara investasi dengan membungakan uang. Perbedaan tersebut dapat ditelaah dari definisi hingga makna masing-masing 


\section{Islãmadîna \\ JURNAL PEMIKIRAN ISLAM}

Volume XVIII, No. 2, Juni 2017 : 21-40

(Antonio, 2001: 59).

1. Investasi adalah yang mengandung resiko karena berhadapan dengan unsur ketidak pastian. Dengan demikian, perolehan kembaliannya(return) tidak pasti dan tidak tetap.

2. Membungakan uang adalah kegiatan usaha yang kurang mengandung risiko karena perolehan kembaliannya berupa bunga yang relatif pasti dan tetap.

Islam mendorong masyarakat ke arah usaha nyata dan produktif. Islam mendorong seluruh masyarakat untuk melakukan investasi dan melarang membungakan uang. Sesuai dengan definisi di atas, menyimpan uang di bank Islam termasuk kategori kegiatan investasi karena perolehan kembaliannya (return) dari waktu ke waktu tidak pasti dan tidak tetap. Besar kecilnya perolehan kembali itu bergantung pada hasil usaha yang benar-benar terjadi dan dilakukan bank sebagai mudharib atau pengelola dana.

Dengan demikian, bank Islam tidak dapat sekadar menyalurkan uang. Bank Islam harus terus berupaya meningkatkan kembalian atau return of investmen sehingga lebih menarik dan lebih memberi kepercayaan bagi pemilik dana (Antonio, 2001: 60).

\section{Perbedaan Antara Menabung di Bank syariah dan di Bank Konvensional .}

Sepintas, secara teknis fisik, menabung di bank syariah dengan yang berlaku di bank konvensional hampir tidak ada perbedaan. Hal ini karena baik bank syariah maupun bank konvensional di haruskan mengikuti aturan teknis perbankan secara umum. Akan tetapi, jika diamati secara mendalam, terdapat perbedaan besar di antara keduanya (Antonio, 2001: 157).

Perbedaan pertama terletak pada akad. Pada bank syariah, semua transaksi harus berdasarkan akad yang di benarkan oleh syariah. Dengan demikian, semua transaksi itu harus mengikuti kaidah dan aturan yang berlaku pada akad-akad mu'amalah syari'ah. Pada bank konvensional, transaksi pembukaan rekening, baik giro, tabungan, maupun deposito, berdasarkan perjanjian titipan, namun perjanjian titipan ini tidak mengikuti prinsip manapun dalam mua'amalah syari'ah, misalnya wadi'ah. karena, salah satu penyimpangan diantaranya menjanjikan imbalan dengan tingkat bunga tetap terhadap uang yang disetor.

Perbedaan kedua terdapat pada imbalan yang di berikan. Pada bank konvensional menggunakan konsep biaya (cost concept) untuk menghitung 
keuntungan. Artinya, bunga yang dijanjikan di muka kepada nasabah penabung merupakan ongkos yang harus dibayar olah bank. Karena itu, bank harus menjual kepada nasabah lainnya (peminjam) dengan biaya (bunga) yang lebih tinggi. Perbedaan keduanya disebut spread. Jika bunga yang dibebankan kepada yang dibebanan kepada peminjam lebih tinggi dari bunga yang harus di bayar kepada nasabah penabung, bank mendapatkan spread postif. Jika bunga yang diterima dari si peminjam lebih rendah, terjadi spread negatif bagi bank. Bank harus menutupnya dengan keuntungan yang dimiliki sebelumnya. Jika tidak ada, ia harus menanggulanginya dengan modal.

Bank syari'ah menggunakan profit sharing artinya dana yang diterima bank disalurkan kepada pembiayaan. Keuntungan yang didapatkan dari pembiayaan tersebut dibagi dua, untuk bank dan untuk nasabah, berdasarkan perjanjian pembagian keuntungan dimuka (biasanya terdapat dalam formulir pembukaan rekening yang berdasarkan mudhorobah).

Perbedaan ketiga adalah sasaran kredit/pembiayaan. Para penabung di bank konvensional tidak sadar bahwa uang yang ditabungnya diputarkan kepada semua bisnis, tanpa memandang halal-haram bisnis tersebut, bahkan sering terjadi dana tersebut digunakan untuk membiayai proyek-proyek grup perusahaan tersebut. Celakanya, kredit itu diberikan tanpa memandang apakah jumlahnya melebihi batas maksimum pemberian kredit (BMPK) ataukah tidak. Akibatnya, ketika krisis datang dan kredi-kreit itu bermasalah, bank sulit mendapatkan pengembalian dana darinya.

Adapun dalam bank syari'ah, penyaluran dana simpanan dari masyarakat dibatasi oleh dua prinsip dasar, yaitu prinsip syari'ah dan prinsip keuntungan. Artinya, pembiayaan yang mau diberikan harus mengikuti kriteria-kriteria syari'ah, disamping pertimbangan-pertimbangan keuntungan. Misalnya, pembiayaan-pembiayaan (kredit) harus kepada bisnis yang halal, tidak bolehkepada perusahaan atau bisnis yang memproduksi makanan atau minuman yang diharamkan, perjudian, pornografi dan bisnis lain yang tidak sesuai dengan syari'ah. Karena itu menabung di bank syari'ah relatif lebih aman ditinjau dari perspektip Islam karena akan mendapatkan keuntungan yang didapat dari bisnis yang halal.

\section{Faktor yang Mempengaruhi Investasi}

1. Suku Bunga

Suku bunga dapat dipandang sebagai pendapatan yang diperoleh dari melakukan tabungan. Suatu rumah tangga akan membuat lebih banyak 


\section{Islãmadîna \\ JURNAL PEMIKIRAN ISLAM}

tabungan apabila suku bunga tinggi karena lebih banyak pendapatan dari penabung akan diperoleh. Pada suku bunga rendah orang tidak begitu suka membuat tabungan karena mereka merasa lebih baik melakukan pengeluaran

konsumsi atu berinvestasi daripada menabung. Dengan demikian apabila suku bunga rendah masyarakat cenderung menambah pengeluaran konsumsinya atau pengeluaran untuk berinvestasi (Sadono, 2006).

Pengaruh dari suku bunga kredit terhadap investasi dijelaskan oleh pemikiran ahli-ahli ekonomi Klasik yang menyatakan bahwa investasi adalah fungsi dari tingkat bunga. Pada investasi, semakin tinggi tingkat bunga maka keinginan untuk melakukan investasi juga makin kecil. Alasannya, seorang investor akan menambah pengeluaran investasinya apabila keuntungan yang diharapkan dari investasi lebih besar dari tingkat bunga yang harus dia bayarkan untuk dana investasi tersebut yang merupakan ongkos dari penggunaan dana (cost of capital). Semakin rendah tingkat bunga, maka investor akan lebih terdorong untuk melakukan investasi, sebab biaya penggunaan dana juga semakin kecil (Nopirin, 1992).

2. Tingkat Inflasi

Inflasi adalah kecenderungan kenaikkan harga secara umum dan terusmenerus. Kenaikan harga dari satu atau dua barang saja tidak dapat disebut sebagai inflasi, kecuali apabila kenaikan tersebut meluas kepada sebagian besar dari barang-barang lainnya. Dalam perekonomian besarnya tingkat inflasi di bawah $10 \%$ per tahun, inflasi ini tergolong inflasi ringan. Besarnya tingkat berkisar antara 10 sampai 30 persen per tahun dikategorikan inflasi sedang. Dan apabila tingkat inflasi berada dikisaran 30 sampai 100 persen per tahun dikategorikan inflasi berat. Dalam kisaran tertentu inflasi juga dapat mencapai ratusan bahkan ribuan persen per tahun, sebagai akibat dari resesi ekonomi maupun sebab-sebab lain, inflasi ini tergolong dalam hiperinflasi (Boediono, 1989).

Berdasarkan faktor-faktor yang menimbulkannya, inflasi dapat dibedakan menjadi dua jenis (Sadono, 2006) yaitu : a) Inflasi Tarikan Permintaan (Demand Pull Inflation) b) Inflasi Desakan Biaya (Cosh Pull Inflation)

3. Tenaga Kerja

Sumber daya manusia (SDM) atau Human Resources mengandung dua pengertian yaitu pertama, sumber daya manusia mengandung pengertian 
usaha kerja atau jasa yang dapat diberikan dalam proses produksi. Dalam hal ini sumber daya manusia mencerminkan kualitas usaha yang diberikan oleh seseorang dalam waktu tertentu untuk menghasilkan barang dan jasa.

Kedua, Sumber daya manusia menyangkut manusia yang mampu bekerja untuk memberikan jasa atau usaha kerja. Mampu bekerja berarti mampu melakukan kegiatan yang mempunyai nilai ekonomis, yaitu bahwa kegiatan tersebut menghasilkan barang atau jasa untuk memenuhi kebutuhan masyarakat. Secara fisik kemampuan bekerja diukur dengan usia. Dengan kata lain, orang dalam usia kerja dianggap mampu bekerja. Kelompok penduduk dalam usia kerja tersebut dinamakan tenaga kerja atau Man power. Secara singkat tenaga kerja didefinisikan sebagai penduduk dalam usia kerja (Payaman J. Simanjuntak, 2001).

\section{Nilai Tukar (Kurs)}

Nilai tukar atau kurs merupakan harga mata uang satu negara terhadap harga mata uang negara lain. Menurut Krugman (2000) mengartikan nilai tukar adalah harga sebuah mata uang dari sebuah Negara yang diukur dan dinyatakan dengan mata uang lain. Nilai tukar mata uang dapat didefinisikan sebagai harga relatif dari mata uang terhadap mata uang Negara lainnya. Pergerakan nilai tukar di pasar dapat dipengaruhi oleh faktor fundamental dan non fundamental. Faktor fundamental ini tercermin dari variable-variabel ekonomi makro.

\section{METODOLOGI PENELITIAN}

Penelitian ini digolongkan pada penelitian kuantitatif dengan menggunakan dua variabel yaitu variabel bebas (bagi hasil) dan variabel terikat (minat nasabah). Penelitian dilakukan pada Bank Pembiayaan Rakyat Syariah (BPRS) Bangun Drajat Warga Yogyakarta

Dalam penelitian ini, populasi adalah seluruh nasabah BPR Syariah Bangun Drajat Warga. Sedangkan sampel diperoleh menggunakan Technigue Convenience Sampling yaitu pengambilan sampel dengan memilih nasabah yang mudah ditemui atau dimintai informasi, jumlah sampel pada penelitian ini sebanyak 30 responden.

Penelitian ini menggunakan uji instrument kepada 20 responden dalam rangka menguji tingkat validitas untuk menguji kevalidan atau kesahihan suatu instrumen dan reabilitas instrument bertujuan untuk mengetahui sejauh mana suatu alat pengukur dapat dipercaya atau diandalkan. 
Adapun metode pengumpulan data yang digunakan dalam penelitian ini adalah melalui survey dengan mendistribusikan kuesioner yang berisi pernyataan-pernyataan mengenai keinginan berinvestsi nasabah di perbankan syariah kepada responden. Analisis menggunakan analisis Correlations Product Moment Pearson untuk mengetahui hubungan bagi hasil terhadap minat nasabah berinvestasi dengan bantuan SPSS (Statistik Package for Social Science).

\section{HASIL DAN PEMBAHASAN}

\section{Uji Validitas}

Uji validitas dalam penelitian ini menggunakan analisis korelasi Pearson's Correlation Product Moment. Data diolah dengan bantuan program SPSS for windows Release 17.0.

Hasil pengolahan data dengan menggunakan program SPSS diperoleh hasil seperti dalam tabel berikut.

Uji Validitas

\begin{tabular}{ccc}
\hline Butir & Sig & Keterangan \\
\hline 1 & 0,000 & Valid \\
2 & 0,000 & Valid \\
3 & 0,000 & Valid \\
4 & 0,000 & Valid \\
5 & 0,000 & Valid \\
6 & 0,000 & Valid \\
7 & 0,000 & Valid \\
8 & 0,000 & Valid \\
9 & 0,000 & Valid \\
10 & 0,011 & Valid \\
11 & 0,014 & Valid \\
12 & 0,004 & Valid \\
13 & 0,002 & Valid \\
14 & 0,001 & Valid \\
15 & 0,000 & Valid \\
16 & 0,022 & Valid \\
17 & 0,018 & Valid \\
\hline
\end{tabular}




\begin{tabular}{ccc}
\hline 18 & 0,000 & Valid \\
19 & 0,000 & Valid \\
20 & 0,000 & Valid \\
\hline \multicolumn{3}{c}{ Sumber data diolah }
\end{tabular}

Tabel di atas menunjukkan nilai signifikansi yang diperoleh pada masing-masing butir pertanyaan variabel minat nasabah lebih kecil dari 0,05 (Sugiyono, 2010 : 231).Hal ini berarti seluruh butir pertanyaan pada variabel sistem bagi hasil adalah valid dan dinyatakan layak dipakai dalam penelitian.

\section{Uji Reabilitas}

Uji reliabilitas digunakan untuk mengetahui tingkat keandalan (reliabilitas) angket untuk menjadi alat pengukur. Pengujian reliabilitas menggunakan rumus Cronbach Alpha. Adapun secara ringkas hasil uji reliabilitas ditunjukkan. Hasil reliabilitas untuk item-item pertanyaan untuk setiap variabel yaitu sistem bagi hasil dan keinginan berinvestasi dapat dirangkum dalam tabel sebagai berikut:

Ringkasan Hasil Uji Reliabilitas

\begin{tabular}{lll}
\hline \multicolumn{1}{c}{ Variabel } & Koefisien Alpha & Keterangan \\
\hline Sistem Bagi Hasil & 0,904 & Reliabel/ Andal \\
Keinginan Berinvestasi & 0,675 & Reliabel/ Andal \\
\hline \multicolumn{1}{c}{ Sumber: data diolah } & &
\end{tabular}

Hasil perhitungan uji reliabilitas menggunakan Alpha Cronbach menghasilkan nilai Alpha variabel sistem bagi hasil sebesar 0,904 dan variabel keinginan berinvestasi sebesar 0,675. Nilai Alpha tersebut lebih besar dari 0,60 sehingga kedua variabel dinyatakan sandal/reliabel dengan harga koefisien reliabelitas tinggi (antara 0,600 sampai dengan 0,800).

\section{Uji Korelasi}

Untuk mengetahui hubungan antara sistem bagi hasil di lembaga keuangan syariah terhadap keinginan berinvestasi nasabah di perbankan syariah. Berikut ini adalah hasil pengujian hipotesis dengan menggunakan uji korelasi dengan Product Moment Pearson.

Hasil Pengujian Hipotesis dengan Uji Korelasi Pearson

\begin{tabular}{lcccc}
\hline Keterangan & $\begin{array}{l}\text { Pearson } \\
\text { Correlation }\left(\mathrm{r}_{\text {hitung }}\right)\end{array}$ & rtabel & p-value & Kesimpulan \\
\hline $\begin{array}{l}\text { Sistem Bagi Hasil } \\
\text { Keinginan Berinvestasi }\end{array}$ & 0,770 & 0,361 & 0,000 & $\mathrm{H}_{1}$ diterima \\
\hline
\end{tabular}




\section{Islãmadîna

\section{Sumber: data diolah}

Hasil pengujian hipotesis dengan menggunakan Product Moment Pearson menunjukkan bahwa koefisien korelasi ( $\mathrm{r}_{\text {hitung }}$ ) sistem bagi hasil dengan keinginan berinvestasi dengan nilai positif 0,770 berarti lebih besar dari $r_{\text {tabel }}$ $(0,361)$ dan nilai $p$-value $0,000<0,05$ (level of significant $(\alpha)$ yang digunakan). Hal ini menunjukkan bahwa $\mathrm{H}_{1}$ diterima, artinya terdapat hubungan antara sistem bagi hasil dengan keinginan berinvestasi nasabah di BPR Syariah Bangun Drajad Warga Yogyakarta.

Sistem bagi hasil adalah aturan perjanjian berdasarkan hukum Islam antara bank dan pihak lain untuk menyimpan dana atau pembiayaan usaha, atau kegiatan lainnya yang sesuai syari'ah. Bagi hasil merupakan presentase keuntungan yang dibagikan bank kepada nasabahnya atas investasinya sesuai dengan perjanjian. Nasabah mempunyai keinginan untuk berinvestasi pada sebuah bank dengan berbagai alasan, salah satunya adalah sistem bagi hasil yang diterapkan oleh perbankan syari'ah.

Berdasarkan alat analisis yang digunakan untuk mengetahui hubungan sistem bagi hasil dengan keinginan nasabah untuk berinvestasi pada bank syari'ah pada penelitian ini yaitu korelasi Product Moment Pearson. Berdasarkan hasil pengujian tersebut nampak bahwa terdapat hubungan yang kuat antara sistem bagi hasil dengan keinginan nasabah untuk berinvestasi di BPR syariah Bangun Drajat Warga.

Pada BRP Syariah Bangun Drajat Warga sendiri dari hasil wawancaara tak terstruktur dengan nasabah, bahwa nasabah menginvestasikan atau menabung dananya atau uangnya di BPR Syariah Bangun Drajar Warga Yogyakarta sebagian besar memang karena faktor sistem bagi hasil yang digunakan, karena ingin menjalankan syariah agama, bukan semata-mata karena keuntungan yang diperoleh. Sedangkan wawancara tak terstruktur peneliti kepada pihak pengelola BPR Syariah Bangun Drajat Warga Yogyakarta bahwa nisbah bagi hasil yang didistribusikan kepada nasabah sebesar 38\%, nisbah bagi hasil dapat berubah sesuai dengan kesepakatan antara pemilik modal dan BPR Syariah Bangun Drajat Warga Yogyakarta.

\section{KESIMPULAN}

Berdasarkan hasil analisis data, penelitian ini menunjukkan bahwa terdapat hubungan antara sistem bagi hasil dengan keinginan berinvestasi. Hal ini ditunjukkan dari tingkat korelasi sebesar 0,770 dengan signifikansi sebesar 0,000. Apabila signifikansi di bawah atau sama dengan 0,05 maka $\mathrm{H}_{1}$ diterima, 
yang berarti bahwa terdapat hubungan antara sistem bagi hasil dengan keinginan berinvestasi nasabah di perbankan syariah. Oleh karena itu, dapat disimpulkan dengan digunakannya sistem bagi hasil di lembaga keuangan syariah dapat mempengaruhi minat para nasabah untuk menanamkan investasinya di perbankan syari'ah seperti pada BPR Syariah Bangun Drajat Warga Yogyakarta 


\section{Islãmadìna \\ JURNAL PEMIKIRAN ISLAM}

Volume XVIII, No. 2, Juni 2017 : 21-40

\section{DAFTAR PUSTAKA}

Antonio, Muhammad Syafi'i. 2001. Bank Syariah dari Teori ke Praktik. Jakarta : Gema Insani Press.

Arikunto, Suharsimi. 2002. Prosedur Penelitian Suatu Pendekatan Praktek. Jakarta : Rineka Cipta.

Boediono. 1989. Pengantar Ilmu Ekonomi. Yogyakarta : BPFE.

Bungin, Burhan. 2009. Metodologi Penelitian Kuantitatif: Komunikasi, Ekonomi dan Kebijakan Publik serta Ilmu-ilmu Sosial Lainnya. Jakarta: Kencana.

Jogiyanto. 2000. Teori Portofolio dan Analisis Investasi. Yogyakarta: BPFE.

Kuncoro, Mudrajad. 2004. Metode Kuantitatif teori dan Aplikasi untuk Bisnis dan Ekonomi. Yogyakarta: UPP AMP YKPN.

Krugman. 2000. Ekonomi Internasional : Teori dan Kebijakan. Terjemahan DR. Faisal H. Basri, SE MSc. Jakarta : PT Indeks Kelompok Gramedia

Muhammad. 2002. Manajemen Bank Syariah. Yogyakarta : UPP AMP YKPN. . 2005. Manajemen Bank Syariah. Yogyakarta : UPP AMP YKPN. 2005. Manajemen Pembiayaan Bank Syariah. Yogyakarta : UPP AMP YKPN.

Nopirin. 1992. Ekonomi Moneter Edisi I. Yogyakarta : BPFE - UGM

Simanjuntak, Payaman J. 2001. Pengantar Sumber Daya Manusia. Jakarta : LPFE UI.

Sukirno, Sadono. 2000. Makroekonomi Modern Perkembangan Pemikiran Dari Klasik Hingga Keynesian Baru. Jakarta : PT RajaGrafindo Persada.

. 2006. Makroekonomi Teori Pengantar. Jakarta : PT RajaGrafindo Persada.

Sudarso, Heri. 2008. Bank dan Lmbaga Keuangan Syariah Deskripsi dan Ilustrasi. Yogyakarta: EKONISI UII

Sugiyono. 2006. Metodologi Penelitian Kuantitatif Kualitatif R\&D. Bandung : Alfabeta.

Cristopher Pass dan Bryan Lowes.1994. Kamus Lengkap Ekonomi.Edisi Ke 2. Jakarta : Erlangga

Tim Pengembangan Perbankan Syariah IBI. 2001. Konsep, Produk dan Implementasi Operasional Bank Syari'ah. Jakarta : Djambatan 